SIR,-Your leading article (21 September, p. 701) highlights the problems of Negro patients who may have repeated screening tests for sickle-cell disease.

Now that the existence of sickle-cell disease in Britain has been recognized and well publicized I feel that the need for screening should be put in the right perspective on a par with other potentially dangerous problems associated with anaesthesia and surgery. It is advisable to perform routine screening for haemoglobinopathies on hospital attendance, but should the absence of a sickle-cell test in fit and nonanaemic adults and older children of possible Negro descent be a contraindication to general anaesthesia? This is certainly not the practice anywhere in Africa.

The suggestion that medical cards be carried by these patients is the obvious solution, but logically medical cards should be advisable for most patients and should include not only haemoglobinopathies but other relevant information, such as blood group, drug allergy, therapy with steroids, anticoagulants, etc. for the same reasons as sugges:ed in the article.-I am, etc.,

Department of Anaesthesia,

F. F. CASALE Guy's Hospital,
London S.E.1

\section{Familial Trends in Low Birth Weight}

SIR,-I should like to make some comments on the excellent paper of Mr. F. Johnstone and Mrs. Lesley Inglis from Aberdeen (14 September, p. 659). Our theory of the maternal regulation of fetal growth, to which their data conform, was developed from the classical cross-breeding experiments of Sir John Hammond and his colleagues. ${ }^{2}$ These studies and our own data indicated that the regulator acts by means of constraining fetal growth. There is no opposite and equal accelerating mechanism. When maternal constraint is relaxed other biological factors such as maternal stature, weight, and parity make a larger contribution to the individual case.

Analyses of pedigree data ${ }^{3}$ demonstrated a clear sequence of mean birth weights on the distaff side of families ascertained through a small-for-dates of families ascertained inrough a small-for-dates proband. Tiveborn siblings $(2,676 \mathrm{~g})$ and mothers previous liveborn siblings (2,676 g) and mothers $(2,921 \mathrm{~g})$, first cousins through maternal aunts $(3,062 \mathrm{~g})$, maternal aunts themselves $(3,230 \mathrm{~g})$ and uncles $(3,262 \mathrm{~g})$, to first cousins through maternal uncles $(3,375 \mathrm{~g})$. When the proband was large for dates a more complex pattern emerged. The mean birth weight of each class of relative was above average, but the differences between relatives were small. The two classes of first cousin did not differ. The mean birth weight of the fathers in our smallfor-dates series did not differ from that of the for-dates series did not differ from that of the general population, whereas the fathers of our
large-for-dates probands had been heavy at birth, large-for-dates probands had been heavy at birth,
with a mean of $3,806 \mathrm{~g}$. These findings support the with a mean of $3,806 \mathrm{~g}$. These findings support the through mothers only.

Our male and female probands were originally ascertained on a sex-mixed grid. Since boys grow faster than girls in utero a greater degree of confaster than girls in utero a greater degree of constraint was needed for boys to attain the small-fordates criterion than for girls. We used Carter's method of the sex of the proband to test our
theories and also the validity of our data in a theories and also the validity of our data in a
quantitative manner. The predictions were that quantitative manner. The predictions were that ascertainment through a small-for-dates boy should reduce the mean birth weight of all distaff relatives except first cousins through maternal uncles, leaving the sequential order in mean birth weights of kin unchanged. Proband sex should not affect the mean birth weight of distaff relatives of large-for-dates probands, because when maternal large-for-dates probands, factors take up more of constraint is relaxed other factors take up more of
the variance. Our findings are shown in tables I and II and it will be seen that these predictions are fulfilled. It is pertinent to note in the small-fordates data that the amount of difference in mean birth weight of relatives affected by the sex of the proband increases in the same sequence.

TABLE I-Small-for-dates Series. Mean Birth Weights ( $g$ ) of Relatives According to Sex of Proband

\begin{tabular}{|c|c|c|c|c|}
\hline Relative & $\begin{array}{l}\text { Total } \\
\text { No. }\end{array}$ & $\begin{array}{l}\text { Female } \\
\text { Proband }\end{array}$ & $\begin{array}{c}\text { Male } \\
\text { Proband }\end{array}$ & Total \\
\hline $\begin{array}{l}\text { eeborn siblings } \\
\text { thers }\end{array}$ & $\begin{array}{l}198 \\
148\end{array}$ & $\begin{array}{l}2,699 \\
2,971\end{array}$ & $\begin{array}{l}2,617 \\
2,862\end{array}$ & \begin{tabular}{|l|}
2,676 \\
2,921
\end{tabular} \\
\hline $\begin{array}{l}\text { First cousins through } \\
\text { maternal aunts } \\
\text { Maternal aunts ... } \\
\text { Maternal uncles ... }\end{array}$ & $\begin{array}{r}123 \\
114 \\
96\end{array}$ & $\begin{array}{l}3,166 \\
3,343 \\
3,357\end{array}$ & $\begin{array}{l}2,957 \\
3,084 \\
3,116\end{array}$ & $\begin{array}{l}3,062 \\
3,230 \\
3,262\end{array}$ \\
\hline $\begin{array}{l}\text { First cousins through } \\
\text { maternal uncles } \\
\text { Fathers } . . \quad \ldots\end{array}$ & $\begin{array}{l}67 \\
71\end{array}$ & $\begin{array}{l}3,384 \\
3,334\end{array}$ & $\begin{array}{l}3,343 \\
3,334\end{array}$ & $\begin{array}{l}3,375 \\
3,334\end{array}$ \\
\hline
\end{tabular}

TABLE II-Large-for-dates Series. Mean Birt Weights $(g)$ of Relatives According to Sex of Proband

\begin{tabular}{l|c|c|c|c}
\multicolumn{1}{c|}{ Relative } & $\begin{array}{c}\text { Total } \\
\text { No. }\end{array}$ & $\begin{array}{c}\text { Female } \\
\text { Proband }\end{array}$ & $\begin{array}{c}\text { Male } \\
\text { Proband }\end{array}$ & Total \\
\hline Liveborn siblings & 241 & 3,992 & 3,905 & 3,937 \\
Mothers . & 126 & 3,760 & 3,583 & 3,647 \\
First cousins through & & & & \\
maternal aunts & 144 & 3,425 & 3,633 & 3,570 \\
$\begin{array}{l}\text { Maternal aunts . . } \\
\text { Maternal uncles . }\end{array}$ & 110 & 3,460 & 3,674 & 3,596 \\
First cousins through & 118 & 3,629 & 3,629 & 3,629 \\
$\begin{array}{l}\text { maternal uncles } \\
\text { Fathers .. }\end{array}$ & 131 & 3,347 & 3,520 & 3,438 \\
& 96 & 3,783 & 3,819 & 3,806
\end{tabular}

The physiological paths by which human fetal growth is constrained are unknown. Csapo et al..$^{5}$ made elegant experiments in rats which identify oestradiol $17 \beta$ (E2) as the inhibitor of the growth of the conceptus. The mechanisms by which fetal growth is regulated must be relatively subtle, since they are presumably sensitive to continuing information from the conceptus about the amount of growth achieved. There should be a set-point, with sensitivity finer on the minus as opposed to the plus side. Such systems have been established for the control of glucose, temperature, and steroids. ${ }^{6}$ The units are hypothalamic integrating neurones with sensitivities specific to each parameter. In each case the numbers of positively sensitive and negatively sensitive neurones are unequal. This provides plus and minus sensors which are able to control feedback loops on either side of the setpoint, but with unequal strength.

The regulation of fetal growth is more complex than simply keeping the level of a physiological variable within limits at a given time; the distinction is between maintenance of steady growth and maintenance of a steady state. Nevertheless, these systems provide a model for our ooncept of the maternal regulator of fetal growth (see fig.). At both extremes of growth rate the system is non-viable. Within these there is arey area where survival is possible but not probable. In the normal range the regulator is more sensitive below the setpoint than above it. The set-point itself varies from population to population,

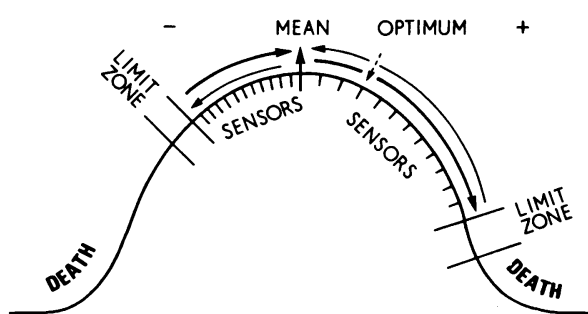

Model of maternal regulator; c.f. Schade's glucostat, thermostat, and steroidstat. ${ }^{6}$ ped:gree to pedigree, woman to woman, but only occasionally from pregnancy to pregnancy.

The great variation in mean birth weight between different ethnic groups may well be adaptive. But for any given population or group optimum birth weight is above mean birth weight. There is thus a selection pressure towards higher birth weight. This system is in a state of evolutionary change; it is dynamic, not static, over generations. Our present theory parsimoniously suggest that a quantitative shift in the numbers of plus and minus sensor neurones by constraint imposed on the female fetus would be adequate to explain the data so far to hand.-I am, etc.

John Radcliffe Hospital

MARGARET OUNSTED

1 Walton, A., and Hammond, J., Proceedings of the Royal Society, $1938,125 \mathrm{~B}, 311$.
Joubert, D. M., and Hammond, J., fournal of Agricultural Science, 1958, 51, 325

Ounsted, M., and Ounsted, C., On Fetal Growth Rate, Clinics in Developmental Medicine, No

Carter, C., and Evans, K. A., Fournal of Medical

and Erdos, T., Lancet,

Schade, J. P., in The Hypothalamus, ed. L. York. Academic Press, 1970.

\section{Experts and Child Abuse}

SIR,-Evil always fascinates; and by concentrating our attention on itself can lead to the neglect of related evils of equal importance. If we hope to improve our care of battered babies we must not forget what we know about the dangers of separating mothers from their infants. The physical health of the baby is of immediate and obvious concern, but its emotional health is quite as important in the long term.

If, as Prof. S. D. M. Court and others suggest (28 September, p. 801), we should admit the child to hospital for "medical and psychiatric as well as social diagnosis of the family whenever there is suspicion" of abuse, I submit that it is equally important that mother should be admitted with the child-that is, to a mother and baby unit. The bond between mother and infant which is the foundation of the child's later emotional health is probably already impaired in such cases; and separate admission of the baby can only confirm and exacerbate the impairment. Primum non nocere.

As well as the advantages this would offer to the precision of the "psychiatric as well as social diagnosis of the family," social workers (who, however young and inexperienced, are daily required to make decisions which would perplex most doctors) might feel less reluctant to refer their cases to a medical team if they were assured in this way that doctors, besides being expert in dealing with physical damage, respected the long-term emotional health of the child as well as they themselves have been taught to respect it.-I am, etc.

Hay on Wye,

JAMES MATHERS

\section{Drug-induced Red Cell Aplasia}

SIR,-Cephalothin has been associated with neutropenia, ${ }^{1}$ thrombocytopenia, ${ }^{2}$ and anaemia with a positive direct Coombs test. ${ }^{3}$ 
We report here the development of severe anaemia due to erythroblastopenia in a patient receiving high doses of cephalothin.

A 67-year-old man had bilateral total hip prostheses for osteoarthritis, the right hip having been replaced in 1969 with a McKee-Farrar prosthesis and the left hip in 1970 with a Charnley prosthesis. In February 1974 an abscess developed in the anterolateral aspect of his right hip. Surgical exploration indicated that the abscess extended into the cavity of the hip joint and alongside the shaft of the femur. A heavy pure growth of greenzone streptococci was cultured.

The patient was initially treated with benzylpenicillin 5 megaunits intravenously six hourly. During the fourth week of treatment he developed During the fourth week of treatment he developed
a diffuse maculoerythematous skin rash which as thought to be due to penicillin allergy. As a result treatment was changed to lincomycin $0.5 \mathrm{~g}$ together with fusidic acid $1 \mathrm{~g}$ six-hourly by mouth. At the same time oral cephalexin was given, starting to $4 \mathrm{~g}$ daily up to a total of $28 \mathrm{~g}$ until the skin rash had completely faded. As there was no clinical evidence of cross-allergenicity these antibiotics were ceased and cephalothin intravenously $4 \mathrm{~g}$ wix-hourly was given with probenecid $2 \mathrm{~g}$ daily for six-hourly was given with probenecid $2 \mathrm{~g}$ daily for
a total of 22 days. The only other drug administered concurrently was diazepam, $2 \mathrm{mg}$ thrice daily.

His blood picture had been normal at the time of admission on 27 February. On 26 April his haemoglobin level had fallen to $8 \mathrm{~g} / 100 \mathrm{ml}$ and the reticulocyte count was less than $1 \%$. Bone marrow biopsy showed normal megakaryocytes and granulocytic series, but there were no red cell precursors. A diagnosis of pure red cell aplasia was made and all medications ceased.

The patient was transfused and six days later erythromycin was started. Reticulocytosis heralded bone marrow recovery and on 11 May, 15 days after repeat bone marrow biopsy showed a return of vigorous normoblastic erythropoiesis. The perivigorous normoblastic erythropoiesis. The peripheral blood picture was completely normal 27
days after ceasing cephalothin. The direct Coombs days after ceasing cephalothin. The direct Coombs
antiglobulin test was first performed 3 months after the aplastic episode and proved negative. It remained negative after incubation of the patient's red cells with varying concentrations of cephalothin.

The offending prosthesis was removed later and convalescence was uneventful. His renal function was normal throughout and appropriate radiological was normal throughout and appropriate radiological
studies excluded thymoma. During the 10 weeks studies excluded thymoma. During the 10 weeks
prior to the first bone marrow biopsy the only other drugs he had received and not mentioned in the above history were clindamycin $300 \mathrm{mg}$ sixhourly for three days approximately five weeks previously, mebhydrolin $1 \mathrm{~g}$ daily for three days for the skin rash, and three Doloxene (aspirin with
dextropropoxyphene) capsules given eight weeks previously.

Pure red cell aplasia is a rare condition and was reviewed recently by Teoh et al., ${ }^{4}$ who described three new cases, in one of which there was an associated thymoma. In another review Recker and Hynes ${ }^{5}$ noted an association between pure red cell aplasia and drug therapy in 40 patients; 21 cases occurred after treatment with chloramphenicol, and other drugs incriminated were sulphathiazole, arsphenamine, penicillin, phenobarbitone, isoniazid, chenopodium, phenylbutazone, tolbutamide and chlorpropamide, and phenytoin.

In our patient the return of erythropoiesis within 15 days of withdrawing cephalothin, diazepam, and probenecid strongly suggests that one of these three drugs was responsible for the erythroblastopenia. We have been unable to find any previous record of pure red cell aplasia being associated with any of these drugs. The clinical history and the references already cited ${ }^{1-3}$ raise the strong possibility of a causal link between ophalothin and red cell aplasia in our patient.-We are, etc.,

D. MaOCulloch

J. M. JACKSON J. VENERYS

Departments of Microbiology, Haematology, and Orthopaedics,
1 Davis, A., et al., Antimicrobial Agents and Chemotherapy, 1963, 3, 272

H. J., fournal of the American Med Horowitz, Hiation, Journal of the
Mon, 203,601 .

3 Molthan, L., Reidenberg, M. M., and Eichman, M. F., New England łournal of Medicine, 1967 277, 123 .

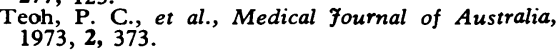
Recker, R. R., and Hynes, H. E., Archives of Internal Medicine, 1969, 123, 445 .

\section{Nephrotic Syndrome in Chronic Lymphatic Leukaemia}

SIR,-We were interested to see the recent paper by Dr. J. R. E. Dathan and others on this subject (14 September, p. 655) since we have recently had two such patients under our care. Both, like the patients described by Dr. Dathan and his colleagues, were middle-aged men. The first patient was aged 64 and presented with a nephrotic syndrome. During investigations of this the diagnosis of chronic lymphocytic leukaemia was established. Renal biopsy showed typical membranous nephropathy on both electron microscopy and immunofluorescent study. He was treated with ahlorambucil, and though proteinuria has diminished and he no longer has oedema, proteinuria persisted and therapy was stopped after one year. This patient is discussed in more detail elsewhere. ${ }^{1}$ The second patient was a man of 57 years when chronic lymphocytic leukaemia was diagnosed. Because heavy proteinuria and ankle oedema were also present he was referred for renal biopsy. This showed sclerosing proliferative glomerulonephritis on light and electron microscopy; immunofluorescent studies were not done. Three years later his nephrotic syndrome persisted with a reduced glomerular filtration rate $(48 \mathrm{ml} / \mathrm{min})$. He reoeived no specific treatment.

There is no doubt that the association between neoplasia and a nephrotic syndrome with evidence of immune complex disorders is a strong one and that the commonest histological appearance in this association is membranous nephropathy. To date we ${ }^{1}$ have noted 27 patients whose nephrotic syndrome and neoplasm were diagnosed within one year of one another and who showed membranous nephropathy on renal biopsy (see table). Only a small number of patients have been reported with proliferative glomerulonephritis, though a number of patients with Hodgkin's disease and minimal ohanges have been described. ${ }^{2} 3$

Sites and Types of Neoplasia Associated with Membranous Nephropathy

\begin{tabular}{|c|c|c|}
\hline Neoplasm & $\begin{array}{c}\text { No. of } \\
\text { Patients } \\
\text { Reported }\end{array}$ & References \\
\hline $\begin{array}{l}\text { Carcinoma of bronchus } \\
\text { Carcinoma of colon or }\end{array}$ & 10 & $1,9-13$ \\
\hline $\begin{array}{l}\text { rectum } \\
\text { Hodgkin's disease* } \\
\text { Carcinoma of mouth or }\end{array}$ & 4 & $\begin{array}{l}1,5,6 \\
1,2,14,15\end{array}$ \\
\hline 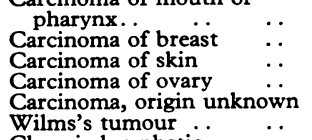 & $\begin{array}{l}2 \\
1 \\
1 \\
1 \\
1 \\
1\end{array}$ & $\begin{array}{l}9 \\
10 \\
9 \\
9 \\
9 \\
1\end{array}$ \\
\hline $\begin{array}{c}\text { Chronic lymphatic } \\
\text { leukaemia }\end{array}$ & 1 & 1 \\
\hline
\end{tabular}

*The patient reported by Miller ${ }^{16}$ as having memsection considered to show minimal changes.

The possibility most investigated is that tumours might release antigens which in turn lead to circulating soluble complexes. ${ }^{4-6}$
In the leukaemias, particularly, the possibility of complexes formed with oncogenic virus antigen also arises. In addition to the evidence from mice that Dr. Dathan and his collsagues quote, the work of Sutherland and Mardiney ${ }^{7}$ is of interest. In a series of 90 patients dying from leukaemias and lymphomas, $10 \%$ showed granular IgG and C3 in their glomeruli, suggesting soluble complex deposition. Further, in two patients with chronic myelocytic leukaemia antigen consistent with the interspecies gs-3 portion of the feline leukaemia virus was demonstrated in kidney homogenates. Anderson and Jarrett $^{8}$ have also shown appearances resembling membranous nephropathy in feline leukaemia, though electron microscopy and immunofluorescence were not done in this study.

We would like to endorse Dr. Dathan's plea that patients with carcinomas, leukaemias, and lymphomas should be investigated for proteinuria regularly and, if it is found, that full investigation including renal biopsy should be performed.-We are, etc.,

Stewart Cameron C. S. OGG

Guy's Hospital,

1 Row, P. G., et al.y Membranous Nephropathy: Long-term Follow-up and Association with 2 Froom, D. W., et al., Archives of Pathology, 1972, 94, 547. Medicine, 1972, 52 et 699 .,

Lewis, M. G., Loughridge, L. W., and Phillips, T. M., Lancet, $1971,2,134$.

Medicine, 1973, 289, 520 .

Couser, W. G., et al., American fournal of Medicine. In press.

Sutherland, J. C., and Mardiney, M. R., fournal of the National Cancer Institute, 1973, S0, 633.
Anderson, L. J., and Jarrett, W. F. H., Research Anderson, L. J., and Jarrett, W. F. H.,

Lee, J. C., Yamauchi, H., and Hopper, J., Annals of Internal Medicine, 1966, 64, 41.
oughridge, L. W., and Lewis, M. G., Lancet, 1971, 1,256.

Nephrologie, et al., fournal d'Urologie et de Asamer, H., Stuhlinger, W., and Dittrich, P., Deutsche medizinische Wochenshrift, 1974, 99, 573.

13 Higgins, M. R., Randall, R. E., and Still, 14 Hardin, J.' G., Coker, A. S., and Blanton, J. H., Southern Medical fournal, 1969, 62, 1111 . Castleman, B., Scully, R. E., and McNeely,
B U., New England fournal of Medicine, 1973, 289, 1241. G., Annals of Internal Medicine, 1967, Miller, D.

\section{Mouth Ulceration and Slow-release} Potassium Tablets

SIR,-Oral potassium supplements are one of the most commonly used medications in the pharmacopoiea. However, the ulcerogenic potential of high concentrations of potassium chloride in contact with mucosal surfaces is well known; both stenosis and perforation of the small intestine have been described.1 ${ }^{2}$ As a result of this, slow-release preparations of potassium chloride have been devised; these incorporate the active agent in a slow-release wax core. I report a case of mouth ulceration in a patient who sucked slow-release potassium tablets.

A 69-year-old European insulin-dependent diabetic was admitted to hospital in May 1974 with ischaemic heart disease, peripheral vascular disease, congestive cardiac failure, and pulmonary oedema. She responded to treatment with digoxin, insulin, diuretics, and potassium supplements in insulin, diuretics, and potassium

Two weeks after admission she was noticed to have developed multiple, well-demarcated, deep 